\title{
Clinical Picture and Antibody Response to Experimental Sarcoptes scabiei var. vulpes Infection in Red Foxes (Vulpes vulpes)
}

\author{
By S. Bornstein, G. Zakrisson and P. Thebo
}

Department of Parasitology, National Veterinary Institute and Swedish University of Agricultural Sciences, Uppsala, Sweden

\begin{abstract}
Bornstein S, G. Zakrisson and P. Thebo: Clinical picture and antibody response to experimental sarcoptes scabiei var. vulpes infection in red foxes (Vulpes vulpes). Acta vet. scand. 1995, 36, 509-519. - Three red foxes (Vulpes vulpes) were experimentally infected with Sarcoptes scabiei isolated from a naturally infected wild red fox. A fourth red fox served as a control. The first signs of sarcoptic mange became evident on the 31 st day post infection (dpi). The signs gradually increased thereafter and between dpi 49 and 77 characteristic lesions of hyperkeratosis developed. Two of the infected foxes developed severe sarcoptic mange, and one of these animals died on dpi 121. The third fox developed a chronic hyperkeratotic lesion on its back, at the site where the mites had been applied. On dpi 127 the surviving foxes were treated systemically with ivermectin, and within 4 weeks the skin lesions had healed except on the pinnae of one animal.

Antibodies to $S$. scabiei var. vulpes were demonstrated in the infected foxes by an ELISA with which seroconversion was seen around 4 weeks post infection (wpi). Western blot analysis of sequential sera of the infected animals demonstrated antibody activity consistently after the 2 nd wpi.

The fourth, non-infected, fox did not show any skin lesions throughout the experimental period nor any specific antibodies to $S$. scabiei var. vulpes.
\end{abstract}

sarcoptic mange; red fox; serodiagnosis; ELISA.

\section{Introduction}

Sarcoptic mange is a skin disease caused by the parasitic mite Sarcoptes scabiei. The parasite can cause severe skin disorders in at least 40 mammalian species, including domestic animals and humans (Fain 1978). It is unclear whether $S$. scabiei isolated from different hosts should be classified as belonging to different species or should be considered as variants (strains) of one species (Arlian 1989). Cross infections do occur between some hosts, but it is unknown to what extent (Arlian 1989). Usually isolates are named after the hosts on which the sarcoptic mites were found, e. g. S. scabiei var. canis, S. scabiei var. vulpes.
S. scabiei infections are endemic in the red fox populations (Vulpes vulpes) of Europe and Russia and in V. fulva of North America (Wetzel \& Rieck 1972, Gerasimoff 1958, Pryor 1956, Zeh 1974). Epizootics have occurred in a number of countries often resulting in high mortality (Olive \& Riley 1948, Trainer \& Hale 1969, Stone et al. 1972, Henriksson 1972, Smith 1978, Holt \& Berg 1990, Mörner 1992). In the mid 1970s S. scabiei hit the wild red fox population in Sweden (Christensson 1972). Within 8 years the infection had spread throughout the mainland of the country, reducing the fox population drastically (Mörner 1992). Outbreaks of 
sarcoptic mange were also reported in farmed foxes in Sweden (Englund 1986a).

In animals with thick protective fur early signs of sarcoptic mange may be easily overlooked. The severe pruritus, which is an early and significant symptom of sarcoptic mange, does not seem to be a regular feature in experimentally infected red foxes (Mörner \& Christensson 1984). According to Stone et al. (1972), pruritus in experimentally infected red foxes $(V$. fulva) is only exhibited during later stages of the disease. However, in Sweden naturally infected wild red foxes showed pronounced pruritus and behavioural disturbances (Borg et al. 1976, Svensson 1983).

The host immune responses to $S$. scabiei infection are not well understood. Circulating specific immunoglobulin has been demonstrated in dogs experimentally and naturally infected with S. scabiei var. vulpes (Bornstein \& Zakrisson 1993), in $S$. scabiei var. suis infected pigs (Matthes et al. 1992, Bornstein et al. 1993), and in S. scabiei var. canis infected rabbits (Arlian et al. 1985). Specific IgE antibodies have been demonstrated in human scabies patients (Rantanen et al. 1981, Dahl et al. 1985).

The clinical symptoms and course of the disease in red foxes have been studied in one experiment on V.fulva in North America (Stone et al. 1972) and in one study on $V$ vulpes in Sweden (Mörner \& Christensson 1984) using moderate and high infective doses, respectively. In this paper the clinical picture and serum antibody responses are described in red foxes $(V$. vulpes) experimentally infected with a relatively low dose of $S$. scabiei var. vulpes.

\section{Materials and methods}

Four, nine-month-old male red foxes $(V$. vulpes), purchased from a fur farm with no previous history of sarcoptic mange, were kept individually in cages outdoors within fenced enclosures free from other wild-life. One uninfected control animal was caged $2 \mathrm{~km}$ away in a separate enclosure.

Special care was taken to avoid any transmission of the mites. When visiting and handling the animals special protective clothing and footwear were worn.

The animals were checked for gut parasites (in fresh faeces left in the cages) by using routine coprological procedures twice before and every week throughout the experiment (White 1964).

\section{Clinical observations}

The animals were closely observed for 4 weeks prior to the trial and clinically examined for any sign of disease, including skin lesions, once daily throughout the trial ( 25 weeks). The animals were restrained by the help of a pair of tongs, and no sedatives or general anaesthesia were used.

\section{Experimental infection}

Three of the red foxes were infected with $S$. scabiei derived from a naturally infected wild red fox, which had been found dead 5 days prior to its arrival at the laboratory. Six pieces, $(2 \times 2$ $\mathrm{cm}^{2}$ ) of the mangy skin were cut out, and the fur on these pieces was cut down to about $10 \mathrm{~mm}$. Three of the pieces were picked at random to serve as infection sources. Then a piece of the mangy skin was held in direct contact with a shaved part of the skin of the midback region of each of the 3 foxes for $5 \mathrm{~min}$. Before carrying out this procedure all 6 pieces of skin had been examined under a stereo-microscope to confirm the presence of $S$. scabiei by warming the pieces to $25-27^{\circ} \mathrm{C}$ for half an hour. The 3 pieces of skin not used for the infection trial were left in Petri dishes at $25-27^{\circ} \mathrm{C}$ for $2 \mathrm{~h}$ and then reexamined. About 200 live mites were found migrating out from each of them.

An amount of $0.2 \mathrm{ml}$ of a $10 \mathrm{mg} / \mathrm{ml}$ solution ivermectin $\left(\right.$ Ivomec $^{\mathrm{R}}$, MSD, Rahway N. J. USA) was injected subcutaneously twice, 14 
days apart, in foxes 1 and 2 starting on the 127 th day post infection (dpi), one week after fox 3 had died.

\section{Laboratory examinations of fur and skin}

Samples from the fur and skin, including the meatuses of the ears, were examined in search for any external parasites or any specific bacterial or fungal infections by using routine laboratory procedures. The analyses were performed at the Laboratories of Parasitology and Bacteriology of the National Veterinary Institute, Uppsala, Sweden, prior to and every third week throughout the trial.

Deep skin-scrapings using scalpel blade were taken from parts of the body where skin lesions were seen once every week throughout the period of infection. The samples were examined under a dissecting microscope in search of mites. If no mites were found the material was put in a $10 \%$ solution of potassium hydroxide for about $5 \mathrm{~h}$ at $37^{\circ} \mathrm{C}$. After centrifugation the supernatant was discarded, and a few drops of glycerine were added to the sediment, which was then re-examined in search of mites and mite eggs.

\section{Blood}

Blood samples were collected by venipuncture at the start of the infection and then once a week for 17 weeks. Sera were prepared and stored at $-20^{\circ} \mathrm{C}$ until used.

\section{Antigen preparation}

The antigen was prepared as previously described (Bornstein \& Zakrisson 1993). Briefly, S. scabiei were isolated from naturally infected wild red foxes. The mites were stored at $-20^{\circ} \mathrm{C}$ until they were thawed and homogenized in a glass grinder in $0.01 \mathrm{M}$ phosphate buffered saline, $\mathrm{pH} 7.2$ (PBS), and ultrasonicated. The supernatant was collected after centrifugation at $3800 \times \mathrm{g}$ for $30 \mathrm{~min}$, filtered through a 0.2 $\mu \mathrm{m}$ filter (Acrodisc, Gelman, Ann Arbor, MI, USA) and stored at $-20^{\circ} \mathrm{C}$ until used. The protein concentration was determined according to Bradford (1976) using bovine serum albumin as standard.

Enzyme-linked immunosorbent assay (ELISA) The indirect ELISA used for determination of S. scabiei antibodies has been previously described as a serological assay for sarcoptic mange in dogs (Bornstein \& Zakrisson 1993a). Briefly, the wells of polystyrene microtitre plates (Greiner Labortechnik, Frickenhausen, Germany) were coated for $24 \mathrm{~h}$ at $4^{\circ} \mathrm{C}$ with 100 $\mu \mathrm{l}$ of the above antigen at a concentration of 3 $\mu \mathrm{g} \mathrm{ml}^{-1}$, diluted in $0.1 \mathrm{M}$ carbonate buffer, $\mathrm{pH}$ 9.6. The coated wells were washed three times with PBS containing 0.05 per cent Tween 20 (PBS-T). Duplicate $100 \mu$ l volumes of the sera to be tested, diluted 1:50 with PBS-T, were added to the antigen-coated wells and incubated for $1 \mathrm{~h}$ at $37^{\circ} \mathrm{C}$. Monoclonal mouse antidog IgG (National Veterinary Institute, Uppsala, Sweden) diluted 1:1500 in PBS-T, rabbit anti-mouse IgG labelled with horse-radish peroxidase diluted 1:1500 in PBS-T, and normal rabbit serum (National Veterinary Institute) diluted $1: 100$ were mixed at $+20^{\circ} \mathrm{C}$ before $100 \mu \mathrm{l}$ was added to the wells and incubated for $1 \mathrm{~h}$ at $37^{\circ} \mathrm{C}$. The wells were then washed 4 times in PBS-T, and $100 \mu \mathrm{l}$ of the substrate solution, which consisted of $0.1 \%$ 5-amino-2-hydroxybenzoic acid (Merck, Darmstadt, Germany), $\mathrm{pH} 5.9$, and $0.05 \%$ hydrogen peroxide were added. The optical density (OD) value was read after $1.5 \mathrm{~h}$ at $492 \mathrm{~nm}$ in a Titertech Multiscan spectrophotometer (Flow Laboratories, Rickmanworth, England).

\section{Polyacrylamide gel electrophoresis and Western blot}

The S. scabiei var. vulpes antigen extract employed in the ELISA was analyzed by polyacryl- 
Table. 1. Appearance of symptoms days post infection (dpi) in 3 red foxes (Vulpes vulpes) experimentally infected with Sarcoptes scabiei var. vulpes

\begin{tabular}{lcccccccc}
\hline & Erythema & $\begin{array}{c}\text { Sebborhea/ } \\
\text { skin scales }\end{array}$ & Crusts & Alopecia & $\begin{array}{c}\text { Hyper- } \\
\text { keratosis }\end{array}$ & $\begin{array}{c}\text { Excori- } \\
\text { ations }\end{array}$ & Odour & Death \\
\hline Fox 1 & 31 & 31 & 34 & 42 & 49 & 57 & - & - \\
Fox 2 & 72 & 42 & 72 & 57 & 57 & 77 & 126 & - \\
Fox 3 & 49 & 57 & 72 & 57 & 63 & 63 & 119 & 121 \\
Fox 4 & - & - & - & - & - & - & - \\
(control) & & & & & & & & \\
\hline
\end{tabular}

amide gel electrophoresis (PAGE) in the presence of sodium dodecyl sulphate (SDS) under reducing conditions and by Western blot (WB) using a Mini-Protean system (Bio-Rad Laboratories, Richmond, CA, USA).

Briefly, before applying the protein sample to a $10 \%$ homogenous slab gel the sample was

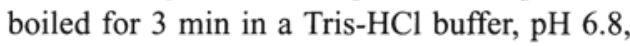
containing $4 \%(\mathrm{w} / \mathrm{v})$ SDS and $50 \mathrm{mM}$ dithiothreitol (DTT). Each track was loaded with a total of $20 \mu \mathrm{g}$ of protein. Molecular weight markers (broad, Bio-Rad Laboratories) were included. The separated polypeptides were visualized by adding $0.1 \%$ Coomassie Brilliant blue R-250 solution (Merck).

For immunoblotting the proteins were separated as described above and electro-transferred to nitrocellulose (NC) paper (Schleicher \& Schuell, Danel, Germany) as described by Towbin et al. (1979). After the transfer the NC papers were blocked with $5 \%$ non-fat milk powder (Semper, Stockholm, Sweden) in Tris- $\mathrm{NaCl}$ buffer, $\mathrm{pH} 7.5$ (TBS) for $2 \mathrm{~h}$ and then washed with TBS containing $0.5 \%$ Tween-20 (TTBS). The blocked NC papers were incubated with the sequential red fox sera, which were diluted 1:50 in TBS containing $1 \%$ nonfat milk powder (AB-buffer). After incubation the NC papers were washed 3 times with TTBS and then incubated with a monoclonal mouse anti-dog IgG (National Veterinary Institute) diluted 1:500 and rabbit anti-mouse IgG conjugated with alkaline phosphatase (ALP), (Dakopatts, Copenhagen, Denmark) diluted 1:1000 in AB-buffer. The ALP was localized with 5-bromo-4-chloro3-indole phosphate p-toulouidine salt and p-nitro blue tetrazolium chloride colour development solutions (Bio Rad Laboratories) in accordance with the manufacturer's instructions.

\section{Results}

Clinical observations

The first signs of dermal disorders seen on the

Table. 2. Sites where signs of sarcoptic mange appeared days post infection (dpi) in 3 red foxes (Vulpes vulpes) experimentally infected with Sarcoptes scabiei var. vulpes

\begin{tabular}{lccccccccc}
\hline & Back & Hock & Thorax & $\begin{array}{c}\text { Hind- } \\
\text { leg }\end{array}$ & Shoulder & $\begin{array}{c}\text { Front- } \\
\text { leg }\end{array}$ & Axilla & $\begin{array}{c}\text { Tail } \\
\text { pinnae }\end{array}$ \\
\hline Fox 1 & 31 & - & 77 & - & - & 127 & - & - & - \\
Fox 2 & 57 & 57 & - & 63 & - & 77 & 126 & - & 126 \\
Fox 3 & 49 & 57 & 114 & 63 & 63 & 84 & 91 & 114 & 119 \\
Fox 4 & & - & - & - & - & - & - & - & - \\
(control) & - & - & - & - & & & & - \\
\hline
\end{tabular}




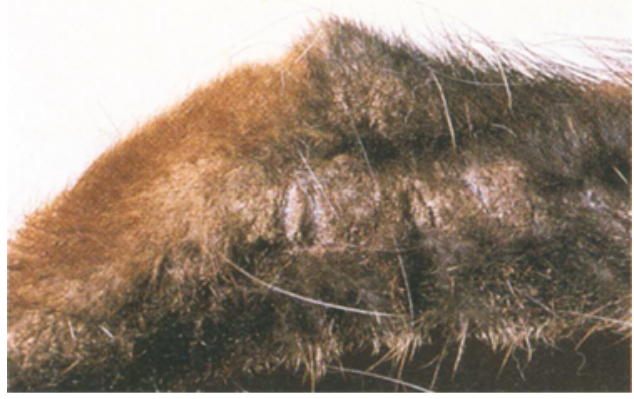

Figure 1. Area of hyperkeratosis on the hock of fox 3, 114 days post-infection with $S$. scabiei var. vulpes.

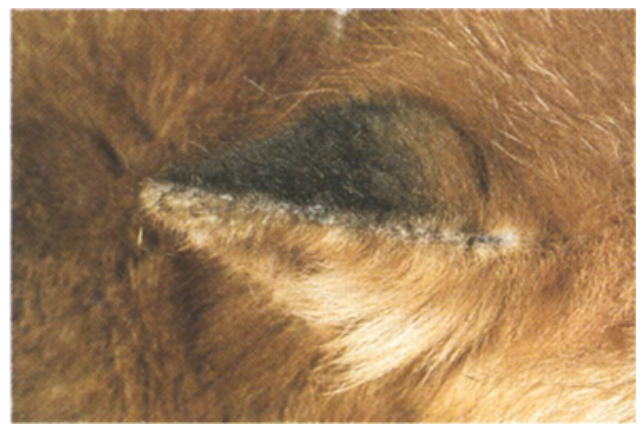

Figure 3. Hyperkeratotic areas on the pinnae of fox 3,126 days post-infection with $S$. scabiei var. vulpes.

infected foxes are summarized in Tables 1 and 2 . On the 31 st day post infection (dpi) erythema, and dry seborrhoea including skinscales were seen on the back of fox 1 in the area where the infected skin had been applied. A few days later crusts followed by alopecia were observed. This area of excematous dermatitis on the back increased in size during the following weeks, and by 49 dpi hyperkeratosis was observed there. A $2 \times 1 \mathrm{~cm}$ large wound was seen at the edge of the dermatitic lesion on dpi 57. Fox 2 had seborrhoea on its back on $42 \mathrm{dpi}$, and fox $3 \mathrm{had}$ small areas of excematous dermatitis on $49 \mathrm{dpi}$, also on the infection site on its back. Excematous dermatitic lesions had developed

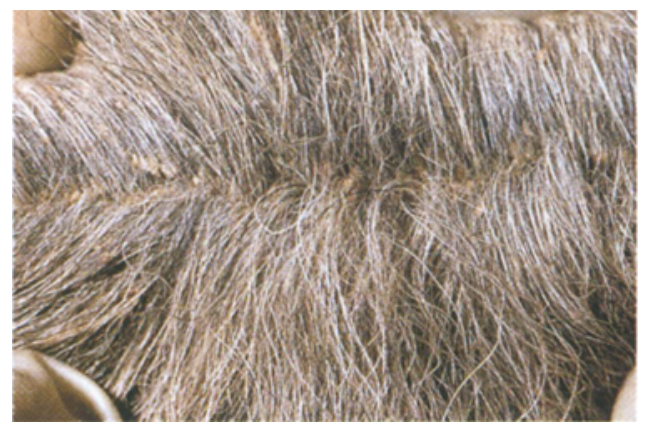

Figure 2. Skin scales seen on the tail of fox 2, 114 days post-infection with $S$. scabiei var. vulpes.

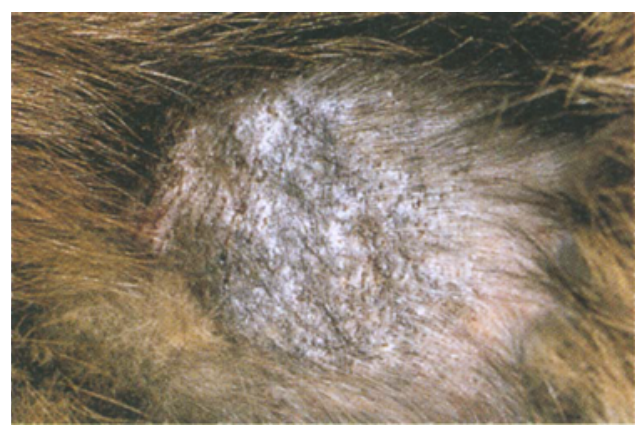

Figure 4. Chronic dermatitis on the back of fox 1 , 126 days post-infection with $S$. scabiei var. vulpes.

with alopecia on the lateral side of the hocks of foxes 2 and 3 by 57 dpi. By 77 dpi the skin lesions on the back of fox 1 had increased in size and intensity. Laterally on the thorax partial alopecia was observed. The lesions on the back of fox 3 had increased, showing excoriations, crusts, seborrhoea and hyperkeratosis. Similar dermatitic lesions had developed on the back of fox 2. On the dermatitic areas on the backs of the foxes regrowth of hairs was seen. Distally on the hind legs, areas of excematous dermatitis with alopecia and dandruff had developed The hairs were loose and could easily be pulled out. Dry skin scales were seen distally on one foreleg of fox 2 . 


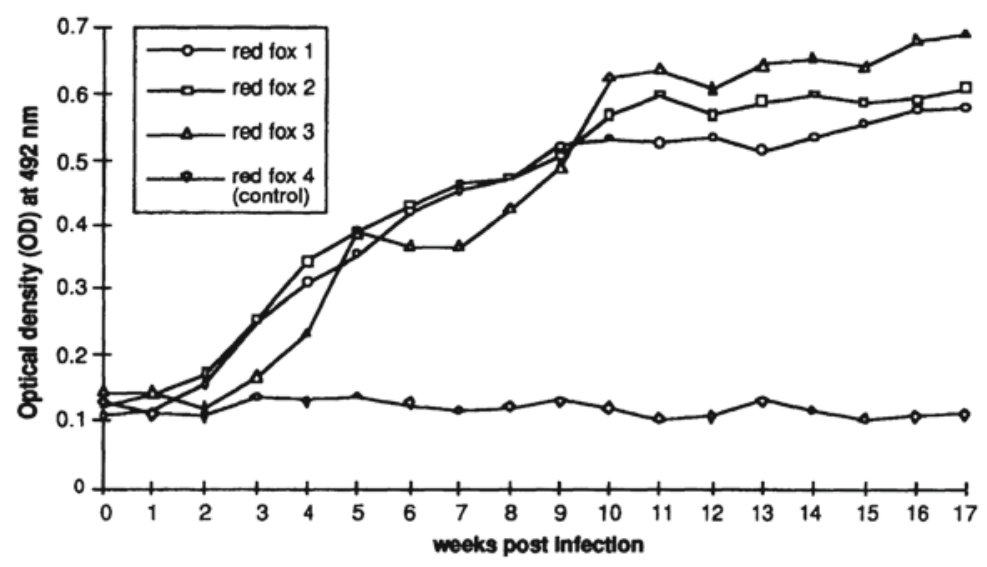

Figure 5. Specific serum antibody responses in 3 red foxes experimentally infected with $S$. scabiei var. vulpes as analysed by ELISA.

On 84 dpi the skin lesions on the back of foxes 2 and 3 were healing. However, the lesions on the hind legs were spreading, particularly on the hocks. Areas of alopecia and seborrhoea were seen on the forelegs from the carpus distally, and partial alopecia was spreading on the hind legs. The skin lesions of foxes 2 and 3 had increased in intensity. Partial alopecia with erythema had appeared in the axillae and on the shoulders of fox 3 . The lesions on the back continued to show new growth of hair. Partial alopecia was continuously spreading posteriorly. The skin lesions on the back of foxes 2 and 3 were smaller in size and intensity than those of fox 1 . By $114 \mathrm{dpi}$ the legs of foxes 2 and 3 were all affected. The lesions had spread distally and upwards, including the hocks and elbows (Fig. 1). The skin of the tail of fox 3 was thickened and rough. When the fur was parted large amounts of dry skin-scales were seen (Fig. 2). None of the infected foxes showed any pruritus when observed.

On 119 dpi a sweet-sour odour emanated from fox 3. The fur was tangled, moist and dirty. Faeces were seen in the sleeping quarter of the animal, and its appetite was reduced. The following day its condition had deteriorated. Half of the feed was left untouched. The eyes were squinting. On 121 dpi the fox was weak, anaemic and dehydrated. The animal did not resist handling, and within another $6 \mathrm{~h}$ it was dead.

On 126 dpi fox 2 exhibited the same symptoms as fox 3 had shown one week earlier. The edges of the pinnae were hyperkeratotic and rough (Fig. 3). The dermatitis on the back of fox 1 was well demarcated from apparently intact skin. The lesion had regressed in size and was about $8 \times 5 \mathrm{~cm}$ large. (Fig. 4). Some dry skin-scales were seen on the forelegs.

The general condition of fox 2 improved a few days after the first injection of ivermectin. A lot of fur was seen on the floor of the cage on the 3rd and 4th day after the first treatment. Six days after the treatment skin-scales were abundant on the affected skin areas. These dry skinscales were adherent to crusts and hairtufts, which could easily be scraped off by hand. The skin lesions of foxes 1 and 2 were healed after 4 weeks albeit small hyperkeratotic areas on the 
edges of the pinnae of fox 2 were still present. Fox 4 (the uninfected control) did not show any skin lesions or clinical signs of dermatological disorders throughout the experimental period.

\section{Faecal examination}

No helminth ova or coccidian oocysts were found.

\section{Laboratory examinations of fur and skin}

The bacteriological and mycological investigations of the fur and skin of the 4 red foxes did not show any specific infection. S. scabiei mites were found in skin-scrapings from the hocks and backs of the infected animals from dpi 36 and on the back of fox 1 throughout the infection.

\section{Antibody response}

The serum antibody response of the red foxes following the infection is shown in Fig. 5.

The mean OD value of the 4 red foxes before the application of the mites was 0.13 ( $\mathrm{SE}=$ $0.01)$. During the course of the infection the OD values of the control animal never exceeded 0.14 . Around 3-4 weeks after the initial infection a gradual increase of the OD values was recorded, and maximum levels of 0.61-0.69 were recorded at the time when the foxes were treated with ivermectin.

\section{Western blot analyses}

The polyacrylamide gel electrophoresis of the S. scabiei extract revealed a large number of polypeptide bands of molecular weights ranging from about 300 to $14 \mathrm{kDa}$, in accordance with previous studies (Bornstein et al. in press). Sequential sera of the infected red foxes in Western blot recognized several antigens with molecular weights ranging from over 300 to 34 kDa (Fig. 6).

Most intensively stained were antigens with estimated molecular weights of $300,164,147$,

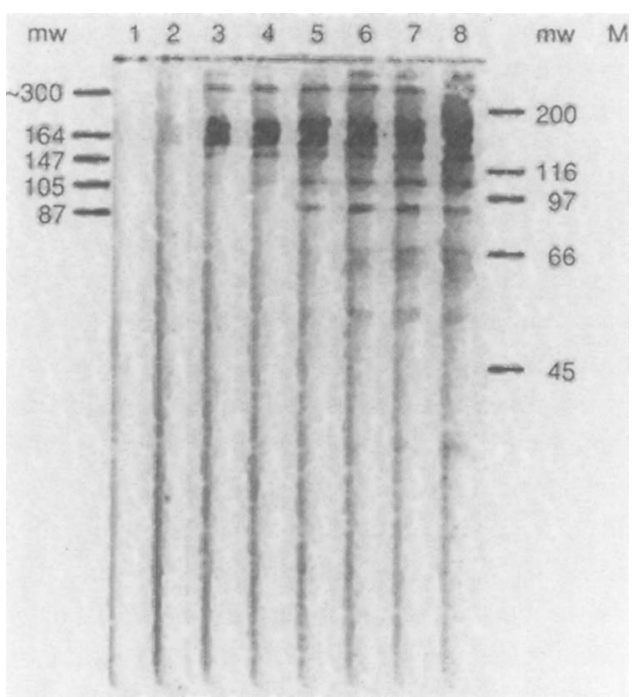

Figure 6. Western blot analysis of S. scabiei var. vulpes extract as recognized by sequential sera of a red fox experimentally infected with $S$. scabiei var. vulpes. Lane 1, serum sampled at the time of infection; lanes $2-8$, sera sampled at 2, 5, 7, 9, 12, 15 and 17 weeks post- infection (wpi), respectively. Molecular weight (mw) markers (broad; Bio Rad Laboratories) indicated to the right in $\mathrm{kDa}$. Estimated molecular weights are indicated to the left.

105 and $87 \mathrm{kDa}$. Less prominent bands were seen at $>300$ and $116 \mathrm{kDa}$, and a group of bands was observed at $66 \mathrm{kDa}$ and below. The first antigens to be recognized were 164 and 147 $\mathrm{kDa}$, both of which were faintly recognized as early as wpi 2 . These bands became more intensively stained later on and were prominent throughout the infection.

\section{Discussion}

There are indications that the incubation period as well as the severity and course of sarcoptic mange are related to the infective dose. In this study the first symptoms of sarcoptic mange in the red foxes were seen as erythema, dry seborrhoea, crusts and partial alopecia about 1 month 
following the application of a relatively low dose of mites (about 200). This low infective dose was believed to tally with the probable low number of mites transmitted under natural conditions as compared to the moderate and high experimental doses used by Mörner \& Christensson (1984) and Stone et al. (1972) in previous studies. Mörner \& Christensson (1984) found the incubation period to be 9-10 days in 2 red foxes that had been experimentally infected with relatively high doses of $S$. scabiei var. vulpes (about 2000). Sixteen red foxes ( $V$. fulva), each infected with relatively moderate doses of $S$. scabiei var. vulpes (about 500), showed an incubation period of 20-30 days (Stone et al. 1972). There are also reports of variation in the incubation period following different doses of S. scabiei mites in pigs (Sheahan 1974, Cargill \& Dobson 1979, Matthes et al. 1990, Bornstein \& Zakrisson 1993b) and dogs (Bornstein 1991).

In our study, one of the foxes died 4 months after application of the mites. In the other fox (no. 2) with generalized mange, death would presumably have followed about a week later, if the animal had not been treated with an acaricide. In the study of Mörner \& Christensson (1984), the 2 foxes died 2-3 months following infection with high doses of mites. In the experiments of Stone et al. (1972), the foxes succumbed to moderate infections after 2-4 months.

As has been observed in natural as well as experimental infections, predilection sites of sarcoptic mange in dogs and other canids, including red foxes, are the hocks, elbows, pinnae, perineum and tail (Folz 1984, Muller et al. 1989, Pence et al. 1983, Mörner 1984). This general pattern was also observed in the present study, although the dermal lesions first developed on the site where the mites had been applied. In one fox the lesion on the back turned into a chronic dermatitis. This animal did not show any other symptoms of mange apart from transient skin scaling on the forelegs and slight partial alopecia laterally on the thorax. The skin lesions on the backs of the other infected foxes healed as the infection spread to recognized predilection sites.

The infected foxes were never seen itching although signs of pruritus, such as excoriations, and alopecia, were observed on the skin. Only mild pruritus was occasionally seen in the two foxes in the study of Mörner \& Christensson (1984), and Stone et al. (1972) did not observe any scratching until late in the infection. However, in the wild, red foxes with observable symptoms of sarcoptic mange have been reported with intense pruritus (Borg et al. 1976, Svensson 1983). The animals in our study were stressed when visited and observed. This might have prevented them from scratching in our presence. Similar behaviour was shown by caged S. scabiei var. vulpes infected dogs (Bornstein 1991) and in farmed foxes (Englund 1986a).

The lack of or suppressed pruritus and alopecia in some infected foxes prevents the observer from detecting the often severe skin lesions hidden under thick fur. The severeness of the disease in red foxes can be overlooked (Englund 1986b, Vanderkop \& Lowes 1992), as was the case in our study of one of the infected animals. This was also true for one of the foxes in the experiment of Mörner \& Christensson (1984). This fox, which had shown mild symptoms of mange, was unexpectedly found dead 2 months following the application of mites (Mörner \& Christensson 1984).

The often highly hyperkeratotic dermatitis of infected red foxes is somewhat comparable to chronic hyperkeratotic scabies in pigs and the crusty (chronic) or "Norwegian" scabies in humans, both of which exhibit mild or no pruritis (Zumpt 1972, Martineau et al. 1987, Arlian 1989). A similar entity has been described in a dog (Anderson 1981). Large numbers of sar- 
coptic mites are always found in the crusts and skin scales of human patients as well as in pigs with hyperkeratotic scabies (Zumpt 1972, Martineau et al. 1987). In and under the crusty skin lesions in infected red foxes massive numbers of mites are generally found (unpublished findings). In the present study, large numbers of mites were also seen in the infected foxes, particularly later during the infection. These constitute fomites with considerable epidemiological significance.

One important contributory factor of the continued epizootic among red foxes in Sweden could possibly be explained by individual animals retaining localized mange lesions and thus act as chronic carriers. In our experiment one of the infected foxes developed a chronic localized mange without any systemic involvement. S. scabiei mites were demonstrated on every occasion that skin scrapings were taken and analysed from the well demarcated hyperkeratotic lesion in this fox. It is not known whether naturally infected wild red foxes with localized lesions of chronic sarcoptic mange lesions survive the infection. Pence et al. (1983) were of the opinion that $3 \%$ of the coyotes infected during the recent epizootic of scabies in Texas USA, survived the disease. However, the authors expressed uncertainty as to the validity of their own interpretation of their observations. Specific antibodies were detected with the ELISA in sera from the infected foxes using the same conjugate reagents that had been used for the analyses of dog sera (Bornstein \& Zakrisson 1993a). Increased antibody levels were evident from 3 to 4 weeks following the application of mites. In experimental studies of $S$. scabiei var. suis in pigs, specific humoral antibodies were detected by ELISA 1-2 weeks earlier in animals that received larger infective doses than in those that had been infected with relatively low doses of mites (Bornstein \& Zakrisson 1993b). It can be expected that the induction of antibodies to
S. scabiei is partly influenced by the condition and number of mites transmitted.

The immunoblot analysis indicated that the antigens recognized by antibodies during the course of infection were apparently the same as those recognized in dogs infected with $S$. scabiei var. vulpes (Bornstein et al. in press). The antibodies reacted with the 164 and $147 \mathrm{kDa}$ antigens already after the second week following the infection.

The ELISA described in this study will most certainly become a useful tool in future epidemiological studies of sarcoptic mange in foxes, as it has already proved useful for the serological diagnosis of sarcoptic mange in dogs (Bornstein \& Zakrisson 1990, Bornstein et al. in press).

\section{Acknowledgements}

We thank Dr. T. Mörner for both giving us access to the animal facilities used and together with Prof. A. Uggla, Dr. Å. Hedhammar and Dr. D. Christensson for valuable comments and to Mr. B. Ekberg for excellent photography.

\section{References}

Anderson RK: Norwegian scabies in a dog: A case report. J. Amer. Anim. Hosp. Assoc. 1981, 17, 101104.

Arlian LG: Biology, host relations, and epidemiology of Sarcoptes scabiei. Ann. Rev. Entomol. 1989, 34, 139-161.

Arlian LG, Runyan RA, Sorlie LB, Vyszenski-Moher $D L$, Estes SA: Characterization of Sarcoptes scabiei var. canis (Acari: Sarcoptidae) antigens and induced antibodies in rabbits. J Med. Entomol. 1985, 22, 321-323.

Borg K, Christensson D, Fabiansson E, Kronevi T, Nilsson PO, Uggla A: Rävskabb i Sverige. (Sarcoptic mange in the red fox in Sweden). Svensk Jakt. 1976, 8, 504-506.

Bornstein S: Experimental infection of dogs with Sarcoptes scabiei derived from naturally infected wild red foxes (Vulpes vulpes): Clinical Observations. Vet. Derm. 1991, 2 151-159.

Bornstein S, Zakrisson G: Ny diagnostik av hundens 
rävskabb (Sarcoptes scabiei). (New diagnostic method of sarcoptic mange in dogs). Svensk Vettidn. 1990, 42, 180-181.

Bornstein S, Zakrisson G: Humoral antibody response in dogs experimentally infected with Sarcoptes scabiei var. vulpes. Vet. Derm. 1993a, 4, 107-110.

Bornstein S, Zakrisson G: Clinical and humoral antibody responses in experimental and spontaneous Sarcoptes scabiei var. suis infected pigs. Vet. Derm. 1993b, 4, 123-131.

Bornstein S, Thebo P, Zakrisson G: Evaluation of an enzymelinked immuno sorbent assay (ELISA) for the serological diagnosis of canine sarcoptic mange. Vet. Derm. 1996. In press.

Bradford MM: A rapid and sensitive method for the quantitation of microgram quantities of protein utilizing the principle of protein-Dye binding. Anal. Biochem. 1976, 72, 248-254.

Cargill CF, Dobson KJ: Experimental Sarcoptes scabiei infestation in pigs. Pathogenesis. Vet. Rec. 1979, 104, 11-14.

Christensson D: Sarcoptes-skabb hos vild rödräv. (Sarcoptic mange in the wild red fox). Svensk Vettidn. 1972, 24, 470-471.

Christensen JD, Schwartz B, Graudal C, Christopherson J. Henriksen SA: Serum IgE antibodies to the scabies mite. Int. J. Dermatol. 1985, 24, 313-315.

Englund L: Sarcoptes skabb hos farmad räv. (Sarcoptic mange in farm foxes). SVAVET. 1986a, 3, 5-6.

Englund L: Rävskabb. (Fox mange). Våra pälsdjur. 1986b, 57, 372-374.

Fain A: Epidemiological problems of scabies. Int. J. Dermatol. 1978, 17, 20-30.

Folz SD: Canine Scabiei (Sarcoptes scabiei Infestation). Compen. Contin. Educ. Pract. Vet. 1984, 6, 176-180.

Gerasimoff $Y A$ : Mange in wild foxes. Translation of Russian Game Reports. 1958. vol.3, Can. Dep. North. Affairs Nat. Resourc. Ottawa.

Henriksson $K$ : Kettujen tarttuva syyhytauti suomessa. (Sarcoptic mange in wild red fox in Finland). Soumen Riista. 1972, 23, 127-135.

Holt $G, B \operatorname{Berg} C$ : Sarcoptesskabb hos rodrev og andre viltlevande rovdyr i Norge. (Sarcoptic mange in red foxes and other wild carnivores). Norsk VetTidskr. 1990, 102, 427-432.

Martineau GP, Van Neste D, Charette R: Compen. Contin. Educ. Pract. Vet. 1987, 9, 51-58.

Matthes HF, Nöckler K, Hiepe Th: Klinischer Verlauf spontaner und experimenteller Sarcoptes suis infektionen beim Schwein. (Clinical picture in natural and experimental Sarcoptes suis infected swine). Mh. VetMed. 1990, 45, 706-709.

Muller GH, Kirk RW, Scott DW: Small Animal Dermatology. 4th ed. Philadelphia: W. B. Saunders, 1989, 351-360.

Mörner T: The epizootic outbreak of sarcoptic mange in Swedish red foxes (Vulpes vulpes). Proc $4^{\text {th }}$ Int. Conf. Wildl. Sydney. Australia. 1981, 124-130.

Mörner T: Sarcoptic mange in Swedish wildlife. Rev. Sci. Tech. Off. Int. Epiz. 1992, 11, 1115-1121.

Mörner T, Christensson D: Experimental infection of red fox (Vulpes vulpes) with Sarcoptes scabiei var. vulpes. Vet. Parasitol. 1984, 15, 159-164.

Olive JR, Riley, $C U$ : Sarcoptic mange in the red fox in Ohio. J. Mammal. 1948, 29, 73-74.

Pence DB, Windberg, LA, Pence, BC, Sprowls R: The epizootiology and pathology of sarcoptic mange in coyotes, Canis latrans, from south Texas. J. Parasitol. 1983, 69, 1100-1115.

Pryor LB: Sarcoptic mange in wild foxes in Pennsylvania. J. Mammal. 1956, 37, 90-93.

Rantanen T, Björksten F, Reunala T, Salo OP: Serum IgE antibodies to scabies mite. Acta Derm. Venerol. $1981,61,358-361$.

Sheahan BJ: Experimental Sarcoptes scabiei infection in pigs: Clinical signs and significance of infection. Vet. Rec. 1974, 94, 202-209.

Smith HJ: Parasites of red foxes in New Brunswick and Nova Scotia. J. Wildl. Dis. 1978, 14, 366370.

Stone WB, Parks E, Weber BL, Parks FJ: Experimental transfer of sarcoptic mange from red foxes and wild canids to captive wildlife and domestic animals. N. Y. Fish Game J. 1972, 19, 1-11.

Svensson T: Rävskabb hos räv och hund. (Sarcoptic mange in red foxes and dogs). Jakt och Jägare. 1983, 2, 9-10.

Towbin H, Staehelin T, Gordon J: Electrophoretic transfer of proteins from polyacrylamide gels to nitrocellulose sheets: procedure and some applications. Proc. Natl. Acad. Sci. U.S.A, 1979, 76, 4350-4354.

Trainer DO, Hale JB: Sarcoptic mange in red foxes and coyotes of Wisconsin. Bull. Wildl. Dis. Assoc. 1969, 5, 387-391.

Vanderkop $M$, Lowes $N$ : Sarcoptic mange in ranch foxes. Can. Vet. J. 1992, 33, 473.

Wetzel R, Rieck W: Krankheiten des Wildes, Paul Parey, Hamburg and Berlin, 1972, 172-174. 
White JB: Laboratory aids to clinical diagnosis. 2nd. ed. London. Brit. Vet. Assoc. 1964.

Zeh JB: Infestation of sarcoptic mange on the red fox in New York. N. Y. Fish Game J. 1974, 21, 182183.

Zumpt F: Scabies and Sarcoptic mange. Excerpta Medica. 1972, 2, 198-208.

\section{Sammanfattning}

Klinisk bild och antikroppssvar vid experimentell infektion av Sarcoptes scabiei var. vulpes hos rödräv (Vulpes vulpes).

Tre rödrävar (Vulpes vulpes) infekterades med Sarcoptes scabiei kvalster, som isolerats från naturligt infekterade vilda rödrävar. En fjärde rödräv hölls oinfekterad som kontroll. De första kliniska tecknen på sarcoptesskabb sågs från och med dag 31 efter infektionstillfället (dpi). Symtomen förvärrades gradvis och mellan 49-77 dpi sågs karakteristiska hyperkeratotiska förändringar på samtliga av de infekterade rävarna. Två av djuren utvecklade allvarlig skabb och en av dem dog, 121 dagar efter infektionen. Den tredje smittade räven utvecklade en kronisk hyperkeratotisk dermatit lokalt på ryggen där sarcopteskvalsterna hade anbragts. En vecka efter det att den ena räven hade dött behandlades de övriga infekterade djuren systemiskt med ivermektin 2 gånger med 14 dagars mellanrum. Inom 4 veckor hade hudskadorna läkt utom på öronkanterna på en av rävarna. Antikroppar mot S. scabiei var. vulpes påvisades i serum från de infekterade rävarna med hjälp av en ELISA. Serokonversion sågs omkring 4 veckor efter smittotillfället. Med Western blot kunde antikroppar påvisas redan 2 veckor efter smittotillfället. Den fjärde, oinfekterade, räven visade inga hudförändringar under observationstiden och hade heller inga specifika antikroppar mot $S$. scabiei var. vulpes.

(Received October 31, 1994; accepted July 10, 1995).

Reprints may be obtained from: S. Bornstein, National Veterinary Institute, P.O. Box 7073, S-750 07 Uppsala, Sweden. 
